Article

\title{
Ta-Zr-N Thin Films Fabricated through HIPIMS/RFMS Co-Sputtering
}

\author{
Li-Chun Chang ${ }^{1,2, *}$, Ching-Yen Chang ${ }^{1}$ and Ya-Wen You ${ }^{1}$ \\ 1 Department of Materials Engineering, Ming Chi University of Technology, New Taipei City 24301, Taiwan; \\ a22910936@yahoo.com.tw (C.-Y.C.); tank95173@gmail.com (Y.-W.Y.) \\ 2 Center for Thin Film Technologies and Applications, Ming Chi University of Technology, \\ New Taipei City 24301, Taiwan \\ * Correspondence: lcchang@mail.mcut.edu.tw; Tel.: +886-2-2908-9899
}

Academic Editor: Pascal Briois

Received: 31 August 2017; Accepted: 2 November 2017; Published: 4 November 2017

\begin{abstract}
Ta-Zr-N thin films were fabricated through co-deposition of radio-frequency magnetron sputtering and high-power impulse magnetron sputtering (HIPIMS/RFMS co-sputtering). The oxidation resistance of the fabricated films was evaluated by annealing the samples in a 15-ppm $\mathrm{O}_{2}-\mathrm{N}_{2}$ atmosphere at $600{ }^{\circ} \mathrm{C}$ for 4 and $8 \mathrm{~h}$. The mechanical properties and surface roughness of the as-deposited and annealed thin films were evaluated. The results indicated that the HIPIMS/RFMS co-sputtered Ta-Zr-N thin films exhibited superior mechanical properties and lower surface roughness than did the conventional direct current-sputtered $\mathrm{Ta}-\mathrm{Zr}-\mathrm{N}$ thin films and HIPIMS-fabricated $\mathrm{ZrN}_{x}$ thin films in both the as-deposited and annealed states.
\end{abstract}

Keywords: annealing; HIPIMS; mechanical properties; oxidation resistance

\section{Introduction}

Ta- $\mathrm{Zr}-\mathrm{N}$ coatings have been employed as protective coatings against wear for biomedical implants [1,2] and as diffusion barrier layers in Cu metallization [3]. Ta-rich Ta-Zr-N coatings exhibited enhanced toughness with high hardness [4,5]. In a previous study [6], low-Zr-content $\mathrm{Ta}_{1-x} \mathrm{Zr}_{x} \mathrm{~N}_{y}$ thin films ( $x=0-0.17, y=0.86-1.03$ ) fabricated through conventional reactive direct-current (DC) magnetron co-sputtering exhibited desirable mechanical properties and a restricted increase in surface roughness from $0.9-1.5 \mathrm{~nm}$ to $1.2-1.7 \mathrm{~nm}$ after annealing at $600{ }^{\circ} \mathrm{C}$ in a $15-\mathrm{ppm}_{2}-\mathrm{N}_{2}$ atmosphere for $4 \mathrm{~h}$. The chemical inertness of these films against commercial moldable $\mathrm{SiO}_{2}-\mathrm{B}_{2} \mathrm{O}_{3}-\mathrm{BaO}$-based glass after 500 thermal cycles was experimentally confirmed. Thermal cycling annealing at $270{ }^{\circ} \mathrm{C}$ and $600{ }^{\circ} \mathrm{C}$ in a 15-ppm $\mathrm{O}_{2}-\mathrm{N}_{2}$ atmosphere was a realistic mass production process [7,8]. The smoothing mechanism of coating surfaces is a crucial factor when $\mathrm{Ta}-\mathrm{Zr}-\mathrm{N}$ thin films are deposited as the protective coatings on glass molding dies. High-power pulsed magnetron sputtering (also called high-power impulse magnetron sputtering (HIPIMS) $[9,10]$ ) has broadened the operating window of magnetron sputtering. HIPIMS was proposed as a method for growing high-quality films with dense structure, smooth morphology, and excellent adhesion [11], and has attracted substantial industry and research interest because of its potential use in such applications as wear resistance $[11,12]$ and electric coatings [13]. However, despite its superiority, the mechanism underlying HIPIMS is complex because many factors-particularly pulse parameters-affect the deposition process. The low deposition rate in the HIPIMS process became a drawback for the commercial applications $[10,14]$. Therefore, hybrid processes, such as HIPIMS/DCMS (direct-current magnetron co-sputtering) [15] and HIPIMS/AIP (arc ion plating) [16] were utilized. In this study, co-deposition of radio-frequency magnetron sputtering and HIPIMS (hereafter, HIPIMS/RFMS co-sputtering) was used to improve the 
surface quality (decrease the surface roughness) of Ta-Zr-N thin films, and its effects on the mechanical properties and oxidation resistance of the films were investigated.

\section{Materials and Methods}

An HIPIMS/RFMS co-sputtering system (Figure 1) was employed to deposit Ta-Zr-N thin films on silicon substrates. A $99.95 \%$ pure Ta target was connected to an RF power generator (13.56 MHz), and a 99.9\% pure $\mathrm{Zr}$ target was connected to a SPIK2000A pulse power supply (SPIK 2000A; Shen Chang Electric Co., Taipei, Taiwan) operated in the unipolar negative mode at a constant power of $400 \mathrm{~W}$. Both targets were $76.2 \mathrm{~mm}$ in diameter, and tilted to the vertical axis. The pulse on-time, $t_{\text {on }}$, and pulse off-time, $t_{\text {off }}$, were kept constant at 100 and $3900 \mu \mathrm{s}$, respectively. The duty cycle $\left(t_{\text {on }} /\left(t_{\text {off }}+t_{\text {on }}\right) \times 100 \%\right)$ was maintained at $2.5 \%$. The substrate-to-target vertical distance was $12 \mathrm{~cm}$, and the chamber was pumped to a base pressure of $6.7 \times 10^{-4} \mathrm{~Pa}$. The working pressure was maintained at approximately $0.67 \mathrm{~Pa}$ by flowing an Ar and $\mathrm{N}_{2}\left(\mathrm{Ar}: \mathrm{N}_{2}=9: 1\right)$ gas mixture into the chamber. The substrate holder was rotated at $10 \mathrm{rpm}$ during the process. A pulse bias voltage of $-50 \mathrm{~V}$ was applied to the substrate holder, and the coatings were deposited at $400{ }^{\circ} \mathrm{C}$. Table 1 lists the sputtering powers employed to fabricate the Ta- $\mathrm{Zr}-\mathrm{N}$ thin films; the deposition times were altered to achieve coating thicknesses of $1217-1279 \mathrm{~nm}$. The Ta-Zr-N thin films were further annealed at $600{ }^{\circ} \mathrm{C}$ for 4 and $8 \mathrm{~h}$ in a 15-ppm $\mathrm{O}_{2}-\mathrm{N}_{2}$ atmosphere in a quartz tube furnace.

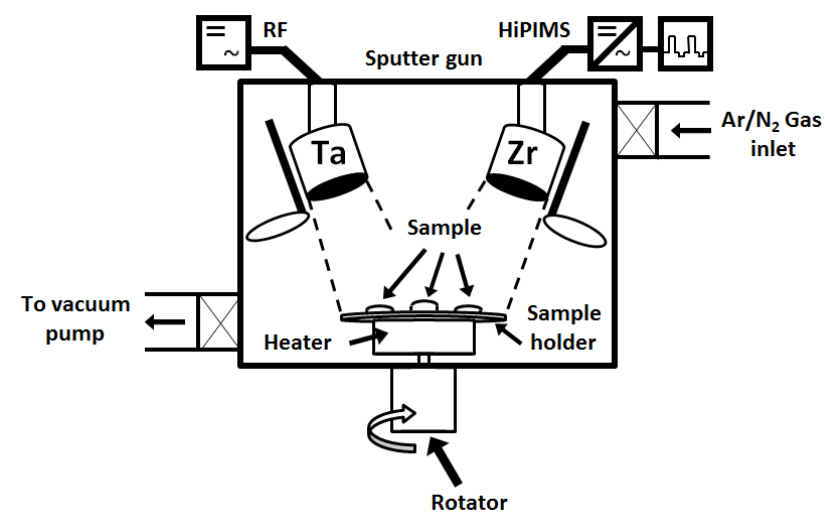

Figure 1. Schematic image of the radio-frequency magnetron sputtering and high-power impulse magnetron sputtering (HIPIMS/RFMS) co-sputtering equipment.

Table 1. Sputter parameters for depositing Ta-Zr-N thin films.

\begin{tabular}{|c|c|c|c|c|c|c|}
\hline Sample & $\begin{array}{c}\text { RF Power } \\
W_{\mathrm{Ta}}\end{array}$ & $\begin{array}{l}\text { HIPIMS } \\
\text { Power } W_{\mathrm{Zr}}\end{array}$ & $\begin{array}{c}\text { Zr Power Density } \\
\left(\mathrm{W} / \mathrm{cm}^{2}\right)\end{array}$ & $\begin{array}{l}\text { Deposition } \\
\text { Time (min) }\end{array}$ & $\begin{array}{c}\text { Coating } \\
\text { Thickness (nm) }\end{array}$ & $\begin{array}{l}\text { Deposition Rate } \\
\text { (nm/min) }\end{array}$ \\
\hline A & 100 & 400 & 1656 & 210 & 1217 & 5.80 \\
\hline B & 200 & 400 & 1632 & 140 & 1238 & 8.84 \\
\hline $\mathrm{C}$ & 300 & 400 & 1576 & 105 & 1279 & 12.18 \\
\hline $\mathrm{D}$ & 400 & 400 & 1500 & 85 & 1253 & 14.75 \\
\hline
\end{tabular}

Chemical composition analysis was conducted by using a field-emission electron probe microanalyzer (FE-EPMA, JXA-8500F, JEOL, Akishima, Japan) on the surface of the samples. The film and oxide scale thicknesses were evaluated by field emission scanning electron microscopy (FE-SEM, S4800, Hitachi, Tokyo, Japan) on the fracture surface of the samples, initiated from the backside of Si wafers. A conventional X-ray diffractometer (XRD, X'Pert PRO MPD, PANalytical, Almelo, The Netherlands) with $\mathrm{Cu} \mathrm{K} \alpha$ radiation was adopted to identify the phases of the coatings, using the grazing incidence technique with an incidence angle of $1^{\circ}$. The nanostructure of the coatings and scales was further examined using transmission electron microscopy (TEM, JEM-2010F, JEOL, Akishima, Japan) at a 200-kV accelerating voltage. TEM samples were prepared by applying a focused ion beam system (FEI Nova 200, Hillsboro, OR, USA) at an accelerating voltage of $30 \mathrm{kV}$ with a gallium ion 
source. A Pt layer was deposited to protect the free surface during sample preparation. The surface nanoindentation hardness values of $\mathrm{Ta}_{1-x} \mathrm{Zr}_{x} \mathrm{~N}_{y}$ coatings were measured with a nanoindentation tester (TI-900 Triboindenter, Hysitron, Eden Prairie, MN, USA). The nanoindenter was equipped with a Berkovich diamond probe tip. The applied load was controlled to exhibit an indentation depth of $100 \mathrm{~nm}$. The loading, holding, and unloading times were $5 \mathrm{~s}$ each. The nanoindentation hardness and reduced elastic modulus $E_{\mathrm{r}}$ of each indent were calculated based on the Oliver and Pharr method [17]. The elastic modulus, $E$, of a film can be determined from:

$$
\frac{1}{E_{\mathrm{r}}}=\frac{1-v^{2}}{E}+\frac{1-v_{\mathrm{i}}^{2}}{E_{\mathrm{i}}}
$$

where $E, v, E_{\mathrm{i}}$, and $v_{\mathrm{i}}$ are the elastic modulus and Poisson's ratio of the film and indenter, using $v=0.25, E_{\mathrm{i}}=1141 \mathrm{GPa}$, and $v_{\mathrm{i}}=0.07$ [18], respectively. The surface roughness values of the coatings were evaluated by using an atomic force microscope (AFM, Dimension 3100 SPM, NanoScope IIIa, Veeco, New York, NY, USA). The scanning area of each image was set at $5 \mu \mathrm{m} \times 5 \mu \mathrm{m}$ with a scanning rate of $1.0 \mathrm{~Hz}$. The residual stress of the films measured by the curvature method was calculated using Stoney's equation [19].

\section{Results and Discussion}

\subsection{As-Deposited Ta-Zr-N Thin Films}

Table 2 lists the elemental compositions of the as-deposited $\mathrm{Ta}-\mathrm{Zr}-\mathrm{N}$ thin films prepared through HIPIMS/RFMS co-sputtering. The Ta content in the Ta-Zr-N thin films increased with increasing Ta target power. The oxygen content in the as-deposited states were 1.0-2.3 at \%. The samples were designated in the form $\mathrm{Ta}_{1-x} \mathrm{Zr}_{x} \mathrm{~N}_{y}$, as follows: $\mathrm{Ta}_{0.84} \mathrm{Zr}_{0.16} \mathrm{~N}_{0.40}, \mathrm{Ta}_{0.81} \mathrm{Zr}_{0.19} \mathrm{~N}_{0.52}, \mathrm{Ta}_{0.58} \mathrm{Zr}_{0.42} \mathrm{~N}_{0.59}$, and $\mathrm{Ta}_{0.33} \mathrm{Zr}_{0.67} \mathrm{~N}_{0.68}$. The atomic ratio of $\mathrm{N} /(\mathrm{Ta}+\mathrm{Zr})$ increased from 0.40 to $0.52,0.59$, and 0.68 as the power of the Ta target increased from 100 to 200, 300, and $400 \mathrm{~W}$, respectively. The deposition parameters were adjusted to fabricate thin films of similar thicknesses (Table 1); the $\mathrm{Ta}_{0.84} \mathrm{Zr}_{0.16} \mathrm{~N}_{0.40}$, $\mathrm{Ta}_{0.81} \mathrm{Zr}_{0.19} \mathrm{~N}_{0.52}, \mathrm{Ta}_{0.58} \mathrm{Zr}_{0.42} \mathrm{~N}_{0.59}$, and $\mathrm{Ta}_{0.33} \mathrm{Zr}_{0.67} \mathrm{~N}_{0.68}$ thin films were 1253, 1279, 1238, and $1217 \mathrm{~nm}$ thick, respectively.

Table 2. Chemical compositions of as-deposited and $600{ }^{\circ} \mathrm{C}$-annealed $\mathrm{Ta}-\mathrm{Zr}-\mathrm{N}$ thin films.

\begin{tabular}{|c|c|c|c|c|c|c|c|}
\hline \multirow{2}{*}{ Sample } & \multirow{2}{*}{$\begin{array}{l}\text { Annealing Time } \\
\text { (h) }\end{array}$} & \multicolumn{4}{|c|}{ Chemical Composition (at \%) } & \multicolumn{2}{|c|}{ Atomic Ratio } \\
\hline & & Ta & $\mathrm{Zr}$ & $\mathbf{N}$ & $\mathbf{O}$ & $\mathrm{Zr} /(\mathrm{Ta}+\mathrm{Zr})$ & $\mathrm{N} /(\mathrm{Ta}+\mathrm{Zr})$ \\
\hline \multirow{3}{*}{ A $\mathrm{Ta}_{0.33} \mathrm{Zr}_{0.67} \mathrm{~N}_{0.68}$} & 0 & $19.0 \pm 0.0$ & $39.1 \pm 0.5$ & $39.6 \pm 0.2$ & $2.3 \pm 0.2$ & 0.67 & 0.68 \\
\hline & 4 & $17.5 \pm 0.4$ & $35.9 \pm 0.3$ & $34.0 \pm 0.7$ & $12.6 \pm 1.0$ & 0.67 & 0.64 \\
\hline & 8 & $16.3 \pm 0.4$ & $33.6 \pm 0.5$ & $30.9 \pm 0.3$ & $19.2 \pm 1.3$ & 0.67 & 0.62 \\
\hline \multirow{3}{*}{ B Ta $0.58 \mathrm{Zr}_{0.42} \mathrm{~N}_{0.59}$} & 0 & $36.3 \pm 0.1$ & $26.1 \pm 0.2$ & $36.6 \pm 0.1$ & $1.0 \pm 0.0$ & 0.42 & 0.59 \\
\hline & 4 & $29.3 \pm 0.5$ & $23.0 \pm 0.8$ & $28.2 \pm 0.5$ & $19.5 \pm 1.5$ & 0.44 & 0.54 \\
\hline & 8 & $27.5 \pm 0.5$ & $21.8 \pm 0.1$ & $26.8 \pm 0.3$ & $23.9 \pm 0.3$ & 0.44 & 0.54 \\
\hline \multirow{3}{*}{$\mathrm{C} \mathrm{Ta}_{0.81} \mathrm{Zr}_{0.19} \mathrm{~N}_{0.52}$} & 0 & $52.5 \pm 0.2$ & $12.5 \pm 0.7$ & $33.5 \pm 0.2$ & $1.5 \pm 0.3$ & 0.19 & 0.52 \\
\hline & 4 & $35.8 \pm 0.4$ & $16.1 \pm 0.4$ & $24.1 \pm 0.0$ & $24.0 \pm 0.3$ & 0.31 & 0.46 \\
\hline & 8 & $33.0 \pm 0.3$ & $14.9 \pm 0.3$ & $22.7 \pm 0.3$ & $29.4 \pm 0.3$ & 0.31 & 0.47 \\
\hline \multirow{3}{*}{$\mathrm{D} \mathrm{Ta}_{0.84} \mathrm{Zr}_{0.16} \mathrm{~N}_{0.40}$} & 0 & $59.3 \pm 0.7$ & $11.0 \pm 0.2$ & $28.3 \pm 0.8$ & $1.4 \pm 0.1$ & 0.16 & 0.40 \\
\hline & 4 & $36.3 \pm 0.5$ & $11.1 \pm 0.8$ & $20.5 \pm 0.2$ & $32.1 \pm 0.3$ & 0.23 & 0.43 \\
\hline & 8 & $35.3 \pm 0.7$ & $11.1 \pm 0.2$ & $18.8 \pm 0.3$ & $34.8 \pm 0.6$ & 0.24 & 0.41 \\
\hline
\end{tabular}

Figure 2 shows the grazing-incident $\mathrm{XRD}$ patterns of the as-deposited $\mathrm{Ta}-\mathrm{Zr}-\mathrm{N}$ thin films. Although the atomic ratio of $\mathrm{N} /(\mathrm{Ta}+\mathrm{Zr})$ deviated from the stoichiometric value of 1 , the $\mathrm{Ta}_{0.81} \mathrm{Zr}_{0.19} \mathrm{~N}_{0.52}, \mathrm{Ta}_{0.58} \mathrm{Zr}_{0.42} \mathrm{~N}_{0.59}$, and $\mathrm{Ta}_{0.33} \mathrm{Zr}_{0.67} \mathrm{~N}_{0.68}$ thin films exhibited a face-centered cubic (fcc) structure. For transition-metal-nitride coatings, $\mathrm{N}$ vacancy concentrations can be up to $50 \%$ [20]. Matenoglou et al. [21] reported that the ternary transition metal nitrides $\mathrm{Ta}_{x} \mathrm{Me}_{1-x} \mathrm{~N}(\mathrm{Me}=\mathrm{Ti}, \mathrm{Zr}, \mathrm{Hf}$, $\mathrm{Nb}, \mathrm{Ta}, \mathrm{Mo}, \mathrm{W})$ formed solid solutions over the entire $\mathrm{x}$ range $(0<x<1)$ and that they were stable in the rock-salt structure regardless of the valence electron configuration of its constituent metals. 
Furthermore, the reflections shift left as $\mathrm{Zr}$ content in the Ta-Zr-N thin films increases because the lattice parameters of standard cubic TaN and $\mathrm{ZrN}$ are $0.4340 \mathrm{~nm}$ (ICDD 49-1283) and $0.4577 \mathrm{~nm}$ (ICDD 35-0753), respectively. By contrast, the $\mathrm{Ta}_{0.84} \mathrm{Zr}_{0.16} \mathrm{~N}_{0.40}$ thin film exhibited a mixture of hexagonal $\beta-\mathrm{Ta}$ [89-1545], hexagonal $\gamma-\mathrm{Ta}_{2} \mathrm{~N}$ (ICDD 26-0985), and cubic ZrN phases, which is attributable to the severe lack of $\mathrm{N}$ content in the thin films. Since the standard Gibbs free energies of the metal nitride formation of $\mathrm{TaN}, \mathrm{Ta}_{2} \mathrm{~N}$, and $\mathrm{ZrN}$ at $400{ }^{\circ} \mathrm{C}$ are $-391,001 \mathrm{~J} /\left(\mathrm{mol}\right.$ of $\left.\mathrm{N}_{2}\right),-420,567 \mathrm{~J} /(\mathrm{mol}$ of $\left.\mathrm{N}_{2}\right)$, and $-602,902 \mathrm{~J} /\left(\mathrm{mol}\right.$ of $\mathrm{N}_{2}$ ) [22], respectively, $\mathrm{ZrN}$ formed preferentially, followed by $\mathrm{Ta}_{2} \mathrm{~N}$. The deficiency of $\mathrm{N}$ in the $\mathrm{Ta}_{0.84} \mathrm{Zr}_{0.16} \mathrm{~N}_{0.40}$ coating resulted in that an excess Ta remained in the $\beta-\mathrm{Ta}$ phase but no $\mathrm{N}$ atoms were available to form TaN. The $\mathrm{N}$ content of the Ta-Zr-N thin films decreased with increasing power supplied on the Ta target $\left(W_{\mathrm{Ta}}\right)$, which was attributed to the re-sputtering of $\mathrm{N}$ atoms from the surface resulting from the increasing energy of bombarding ions [23,24].

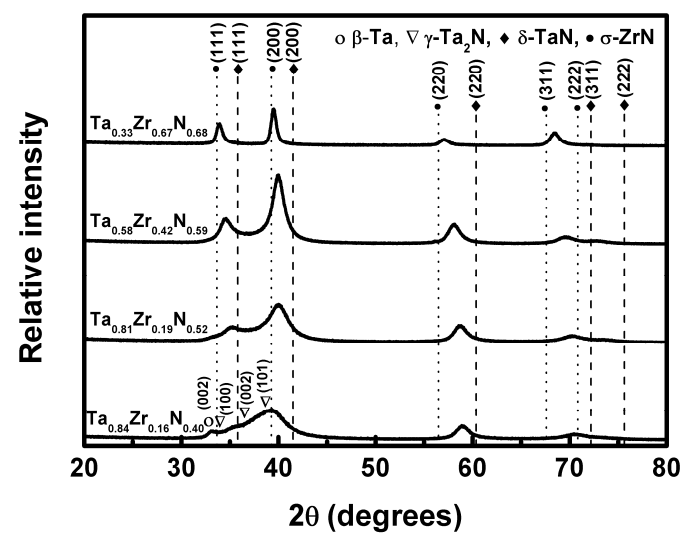

Figure 2. XRD patterns of as-deposited Ta-Zr-N thin films prepared on Si substrates.

Figures 3 and 4 present the AFM and cross-sectional SEM images of the as-deposited Ta-Zr-N thin films, respectively. The $\mathrm{Ta}_{0.84} \mathrm{Zr}_{0.16} \mathrm{~N}_{0.40}, \mathrm{Ta}_{0.81} \mathrm{Zr}_{0.19} \mathrm{~N}_{0.52}$, and $\mathrm{Ta}_{0.58} \mathrm{Zr}_{0.42} \mathrm{~N}_{0.59}$ thin films exhibited a smooth surface and a dense structure with a surface roughness of $0.4-0.5 \mathrm{~nm}$ (Table 3). By contrast, the $\mathrm{Ta}_{0.33} \mathrm{Zr}_{0.67} \mathrm{~N}_{0.68}$ thin film exhibited a coarser columnar structure with a high surface roughness of $2.5 \mathrm{~nm}$. The film structure transition from columnar to dense non-columnar was attributed to the increasing energy of bombarding ions $[25,26]$.

Table 3. Film and oxide scale thicknesses, surface roughness, mechanical properties, elastic recovery, and residual stress values of as-deposited and $600{ }^{\circ} \mathrm{C}$-annealed $\mathrm{Ta}-\mathrm{Zr}-\mathrm{N}$ thin films prepared on Si substrates.

\begin{tabular}{|c|c|c|c|c|c|c|c|c|c|}
\hline \multirow{3}{*}{ Sample } & \multirow{3}{*}{$\begin{array}{l}T_{\mathrm{A}} \\
\text { (h) }\end{array}$} & \multicolumn{2}{|c|}{ Thickness } & \multirow{2}{*}{$\begin{array}{c}\text { Surface } \\
\text { Roughness }\end{array}$} & \multirow{2}{*}{$H$} & \multirow{2}{*}{$E$} & \multirow{2}{*}{$H^{3} / E^{2}$} & \multirow{2}{*}{$W_{\mathbf{e}}$} & \multirow{2}{*}{$\begin{array}{c}\text { Residual } \\
\text { Stress }\end{array}$} \\
\hline & & Film & Oxide & & & & & & \\
\hline & & $(\mathrm{nm})$ & $(\mathrm{nm})$ & $(\mathrm{nm})$ & (GPa) & (GPa) & (GPa) & $\%$ & (GPa) \\
\hline \multirow{3}{*}{$\mathrm{Ta}_{0.33} \mathrm{Zr}_{0.67} \mathrm{~N}_{0.68}$} & 0 & 1217 & 0 & $2.54 \pm 0.01$ & $30.2 \pm 0.9$ & $306 \pm 7$ & 0.30 & 67 & $-4.18 \pm 0.04$ \\
\hline & 4 & 1176 & 0 & $2.93 \pm 0.02$ & $28.3 \pm 1.6$ & $283 \pm 4$ & 0.28 & 63 & - \\
\hline & 8 & 979 & 41 & $3.55 \pm 0.58$ & $19.3 \pm 1.6$ & $235 \pm 7$ & 0.13 & 56 & - \\
\hline \multirow{3}{*}{$\mathrm{Ta}_{0.58} \mathrm{Zr}_{0.42} \mathrm{~N}_{0.59}$} & 0 & 1238 & 0 & $0.52 \pm 0.02$ & $35.0 \pm 0.6$ & $311 \pm 3$ & 0.44 & 73 & $-6.17 \pm 0.47$ \\
\hline & 4 & 1208 & 62 & $0.80 \pm 0.00$ & $25.7 \pm 0.4$ & $262 \pm 3$ & 0.25 & 62 & - \\
\hline & 8 & 1131 & 151 & $1.65 \pm 0.28$ & $24.8 \pm 0.5$ & $268 \pm 4$ & 0.21 & 59 & - \\
\hline \multirow{3}{*}{$\mathrm{Ta}_{0.81} \mathrm{Zr}_{0.19} \mathrm{~N}_{0.52}$} & 0 & 1279 & 0 & $0.36 \pm 0.06$ & $35.5 \pm 0.4$ & $299 \pm 3$ & 0.50 & 76 & $-4.84 \pm 0.04$ \\
\hline & 4 & 1192 & 136 & $1.06 \pm 0.10$ & $21.5 \pm 0.4$ & $254 \pm 6$ & 0.15 & 56 & $-3.46 \pm 0.19$ \\
\hline & 8 & 1149 & 195 & $1.40 \pm 0.24$ & $19.5 \pm 0.3$ & $244 \pm 3$ & 0.13 & 50 & $-2.80 \pm 0.01$ \\
\hline \multirow{3}{*}{$\mathrm{Ta}_{0.84} \mathrm{Zr}_{0.16} \mathrm{~N}_{0.40}$} & 0 & 1253 & 0 & $0.37 \pm 0.01$ & $31.9 \pm 0.8$ & $258 \pm 11$ & 0.49 & 75 & $-4.65 \pm 0.20$ \\
\hline & 4 & 1164 & 131 & $0.54 \pm 0.02$ & $20.9 \pm 0.5$ & $251 \pm 3$ & 0.14 & 56 & $-2.60 \pm 0.17$ \\
\hline & 8 & 1071 & 221 & $1.15 \pm 0.29$ & $18.0 \pm 0.3$ & $235 \pm 2$ & 0.11 & 52 & $-2.80 \pm 0.00$ \\
\hline
\end{tabular}


(a)

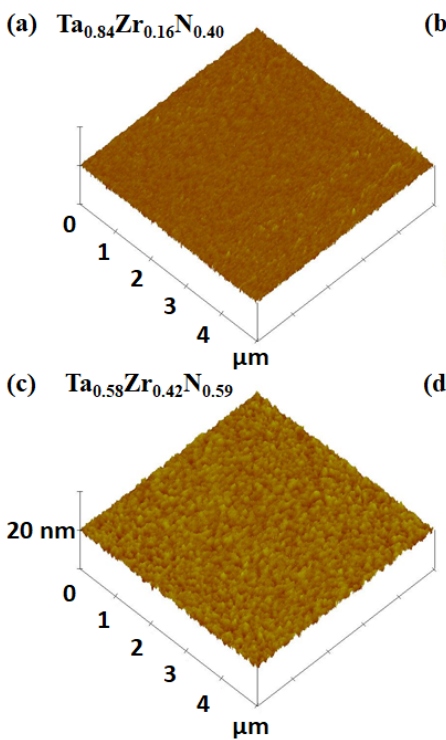

(d)
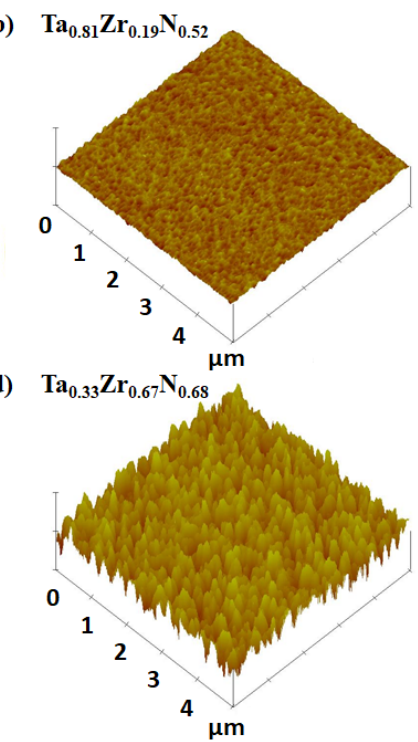

Figure 3. Atomic force microscopy (AFM) images of as-deposited $\mathrm{Ta}-\mathrm{Zr}-\mathrm{N}$ thin films prepared on $\mathrm{Si}$ substrates. (a) $\mathrm{Ta}_{0.84} \mathrm{Zr}_{0.16} \mathrm{~N}_{0.40}$; (b) $\mathrm{Ta}_{0.81} \mathrm{Zr}_{0.19} \mathrm{~N}_{0.52}$; (c) $\mathrm{Ta}_{0.58} \mathrm{Zr}_{0.42} \mathrm{~N}_{0.59}$; (d) $\mathrm{Ta}_{0.33} \mathrm{Zr}_{0.67} \mathrm{~N}_{0.68}$.
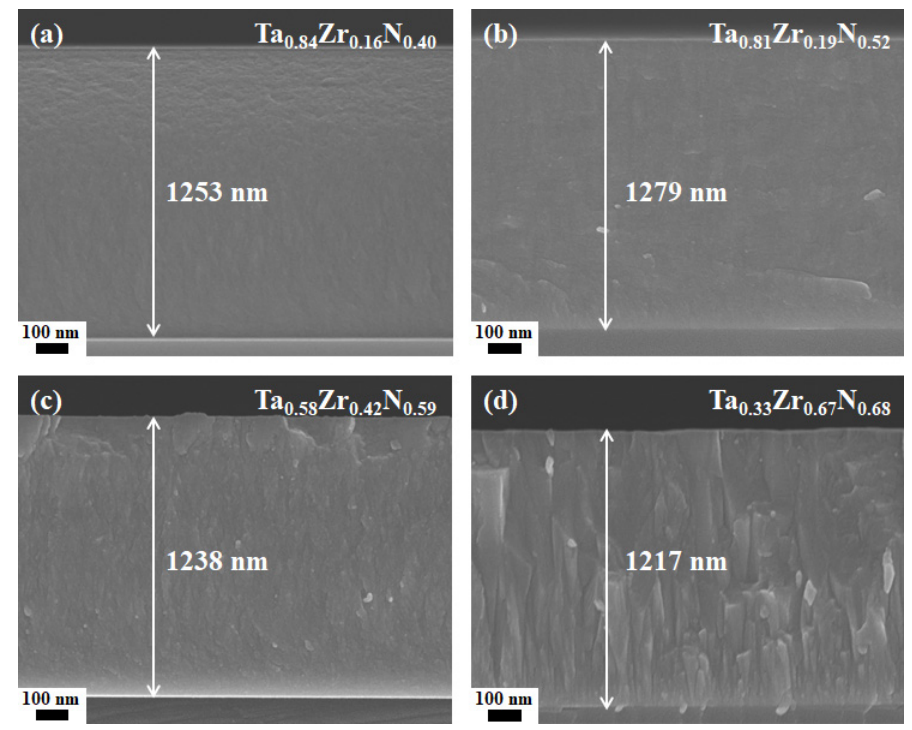

Figure 4. Cross-sectional SEM images of as-deposited Ta-Zr-N thin films prepared on Si substrates. (a) $\mathrm{Ta}_{0.84} \mathrm{Zr}_{0.16} \mathrm{~N}_{0.40}$; (b) $\mathrm{Ta}_{0.81} \mathrm{Zr}_{0.19} \mathrm{~N}_{0.52}$; (c) $\mathrm{Ta}_{0.58} \mathrm{Zr}_{0.42} \mathrm{~N}_{0.59}$; (d) $\mathrm{Ta}_{0.33} \mathrm{Zr}_{0.67} \mathrm{~N}_{0.68}$.

Table 3 shows the mechanical properties of the as-deposited $\mathrm{Ta}-\mathrm{Zr}-\mathrm{N}$ thin films prepared on $\mathrm{Si}$ substrates. The nanoindentation hardness of fcc $\mathrm{Ta}_{0.81} \mathrm{Zr}_{0.19} \mathrm{~N}_{0.52}, \mathrm{Ta}_{0.58} \mathrm{Zr}_{0.42} \mathrm{~N}_{0.59}$, and $\mathrm{Ta}_{0.33} \mathrm{Zr}_{0.67} \mathrm{~N}_{0.68}$ thin films were 35.5, 35.0, and $30.2 \mathrm{GPa}$, respectively, whereas the nanoindentation hardness of the $\mathrm{Ta}_{0.84} \mathrm{Zr}_{0.16} \mathrm{~N}_{0.40}$ thin film with mixed phases was $31.9 \mathrm{GPa}$. The elastic moduli of $\mathrm{Ta}_{0.81} \mathrm{Zr}_{0.19} \mathrm{~N}_{0.52}$, $\mathrm{Ta}_{0.58} \mathrm{Zr}_{0.42} \mathrm{~N}_{0.59}$, and $\mathrm{Ta}_{0.33} \mathrm{Zr}_{0.67} \mathrm{~N}_{0.68}$ thin films were similar $(299,311$, and $306 \mathrm{GPa}$, respectively) because elastic modulus is an intrinsic material property dependent on atomic bonding and crystalline structure [27]. By contrast, the elastic modulus of the $\mathrm{Ta}_{0.84} \mathrm{Zr}_{0.16} \mathrm{~N}_{0.40}$ thin film exhibited a lower value of $258 \mathrm{GPa}$, which was attributed to the implantation of a soft Ta phase. The $H^{3} / E^{2}$ values indicate a resistance to plastic deformation [28], and were $0.49,0.50,0.44$, and 0.30 for the $\mathrm{Ta}_{0.84} \mathrm{Zr}_{0.16} \mathrm{~N}_{0.40}$, $\mathrm{Ta}_{0.81} \mathrm{Zr}_{0.19} \mathrm{~N}_{0.52}, \mathrm{Ta}_{0.58} \mathrm{Zr}_{0.42} \mathrm{~N}_{0.59}$, and $\mathrm{Ta}_{0.33} \mathrm{Zr}_{0.67} \mathrm{~N}_{0.68}$ thin films, respectively. The elastic recovery $W_{\mathrm{e}}[29]$ of the as-deposited $\mathrm{Ta}-\mathrm{Zr}-\mathrm{N}$ thin films exhibited a level of $67 \%-76 \%$. In a previous study using the same sputtering system [30], the HIPIMS-fabricated $\mathrm{ZrN}_{x}$ thin films $(x=0.65-0.78)$ exhibited 
a hardness of 26-27 GPa, a Young's modulus of 260-290 GPa, a residual stress of $-4.2--5.2 \mathrm{GPa}$, and a surface roughness of approximately $0.5 \mathrm{~nm}$ in the as-deposited state. The introduction of $\mathrm{Ta}$ into the $\mathrm{ZrN}$-based thin films evidently raised the hardness values and maintained similar Young's modulus levels.

Aouadi [2] reported the mechanical properties of overstoichiometric Ta- $\mathrm{Zr}-\mathrm{N}$ films deposited by reactive unbalanced magnetron DC sputtering, which exhibited a hardness of $<30$ GPa with a wide range of $\mathrm{Ta} /(\mathrm{Ta}+\mathrm{Zr})$ ratios $(0.16-0.78)$ except for the film with a $\mathrm{Ta} /(\mathrm{Ta}+\mathrm{Zr}$ ) ratio of 0.29 , which exhibited a sudden increased hardness of $37 \mathrm{GPa}$ attributed to solid solution hardening and limited segregation of solutes at grain boundaries. Abadias et al. [4,5] reported a hardness level of $\sim 30 \mathrm{GPa}$ for $\mathrm{Zr}_{1-x} \mathrm{Ta}_{x} \mathrm{~N}$ films ( $x=0.51-0.78$ ) prepared using DC magnetron co-sputtering. The residual stress was $-4.65,-4.84,-6.17$, and $-4.18 \mathrm{GPa}$ for the as-deposited $\mathrm{Ta}_{0.84} \mathrm{Zr}_{0.16} \mathrm{~N}_{0.40}, \mathrm{Ta}_{0.81} \mathrm{Zr}_{0.19} \mathrm{~N}_{0.52}$, $\mathrm{Ta}_{0.58} \mathrm{Zr}_{0.42} \mathrm{~N}_{0.59}$, and $\mathrm{Ta}_{0.33} \mathrm{Zr}_{0.67} \mathrm{~N}_{0.68}$ thin films (Table 3), respectively. These values were more negative than those with similar $\mathrm{Zr} /(\mathrm{Ta}+\mathrm{Zr})$ ratios reported in our previous study [6], in which the residual stress of the DC-sputtered $\mathrm{Ta}_{1-x} \mathrm{Zr}_{x} \mathrm{~N}_{y}$ thin films $(x=0.17-0.72, y=1.03-1.09)$ ranged from 0 to $-2.11 \mathrm{GPa}$. Residual stress affects the hardness of the coatings; in other words, compressive stress increases coating hardness, whereas tensile stress reduces it [31]. The as-deposited Ta-Zr-N thin films with a wide $\mathrm{Zr} /(\mathrm{Ta}+\mathrm{Zr})$ ratio range of $0.16-0.67$ fabricated in this study exhibited nanoindentation hardnesses of 30-35 GPa, superior to the 22-26 GPa reported for the DC-sputtered $\mathrm{Ta}_{0.83} \mathrm{Zr}_{0.17} \mathrm{~N}_{1.03}$, $\mathrm{Ta}_{0.59} \mathrm{Zr}_{0.41} \mathrm{~N}_{1.09}$, and $\mathrm{Ta}_{0.28} \mathrm{Zr}_{0.72} \mathrm{~N}_{1.05}$ thin films [6].

\subsection{Ta-Zr-N Thin Films Annealed in a 15-ppm $\mathrm{O}_{2}-\mathrm{N}_{2}$ Atmosphere at $600{ }^{\circ} \mathrm{C}$}

Table 2 lists the elemental compositions of the Ta-Zr-N thin films annealed at $600{ }^{\circ} \mathrm{C}$ in a $15-\mathrm{ppm}$ $\mathrm{O}_{2}-\mathrm{N}_{2}$ atmosphere for 4 and $8 \mathrm{~h}$. The atomic ratios of $\mathrm{Zr} /(\mathrm{Ta}+\mathrm{Zr})$ of the annealed $\mathrm{Ta}_{0.58} \mathrm{Zr}_{0.42} \mathrm{~N}_{0.59}$ and $\mathrm{Ta}_{0.33} \mathrm{Zr}_{0.67} \mathrm{~N}_{0.68}$ thin films retained their values in the as-deposited states ( 0.42 and 0.67 , respectively), whereas the $\mathrm{Zr} /(\mathrm{Ta}+\mathrm{Zr})$ ratios of the annealed $\mathrm{Ta}_{0.84} \mathrm{Zr}_{0.16} \mathrm{~N}_{0.40}$ and $\mathrm{Ta}_{0.81} \mathrm{Zr}_{0.19} \mathrm{~N}_{0.52}$ thin films increased from 0.16 to 0.23 and from 0.19 to 0.31 , respectively. By contrast, the atomic ratios of Ta: $\mathrm{Zr}$ of the DC-sputtered $\mathrm{Ta}_{1-x} \mathrm{Zr}_{x} \mathrm{~N}_{y}$ thin films $(x=0.05-0.72, y=0.97-1.05)$ [6] retained their preannealing values after annealing at $600{ }^{\circ} \mathrm{C}$ in $15-\mathrm{ppm} \mathrm{O}_{2}-\mathrm{N}_{2}$ for $4 \mathrm{~h}$. Moreover, the DC-sputtered $\mathrm{Ta}_{1-x} \mathrm{Zr}_{x} \mathrm{~N}_{y}$ thin films were near-stoichiometric, whereas the Ta- $\mathrm{Zr}-\mathrm{N}$ thin films in this study were understoichiometric. Furthermore, the DC-sputtered $\mathrm{Ta}_{1-x} \mathrm{Zr}_{x} \mathrm{~N}_{y}$ thin films with a higher $\mathrm{Zr}$ content gathered a higher O content after annealing, which was in contrast to the Ta-Zr-N thin films prepared in this study. The HIPIMS/RFMS-fabricated Ta-Zr-N thin films with a lower $\mathrm{Zr}$ content gathered a higher $\mathrm{O}$ content after annealing. These results implied that the variations of $\mathrm{Zr} /(\mathrm{Ta}+\mathrm{Zr})$ ratio and $\mathrm{O}$ content of the annealed $\mathrm{Ta}-\mathrm{Zr}-\mathrm{N}$ thin films in this study were caused by nonstoichiometric compositions, which contributed a high degree of nonmetal site vacancies in the nitride structure; therefore, $\mathrm{O}$ quickly diffused inward. Conversely, $\mathrm{Zr}$ preferentially diffused outward and reacted with $\mathrm{O}$ to form $\mathrm{ZrO}_{2}$ around the near-surface region because $\mathrm{Zr}$ possesses a lower mass than Ta does, and because the standard Gibbs free energies of the metal oxide formations of $\mathrm{ZrO}_{2}$ and $\mathrm{Ta}_{2} \mathrm{O}_{5}$ at $600{ }^{\circ} \mathrm{C}$ are $-931,249$ and $-663,572 \mathrm{~J}$ per mole of oxygen molecules [22], respectively. Since $\mathrm{ZrO}_{2}$ was the dominant oxide and is not volatile, and the chemical composition analysis was conducted on the surface, the $\mathrm{Zr} /(\mathrm{Ta}+\mathrm{Zr})$ ratios maintained and increased for the high- and low-Zr-content films, respectively. The $\mathrm{N} /(\mathrm{Ta}+\mathrm{Zr})$ ratios of the annealed $\mathrm{Ta}_{0.81} \mathrm{Zr}_{0.19} \mathrm{~N}_{0.52}, \mathrm{Ta}_{0.58} \mathrm{Zr}_{0.42} \mathrm{~N}_{0.59}$, and $\mathrm{Ta}_{0.33} \mathrm{Zr}_{0.67} \mathrm{~N}_{0.68}$ thin films decreased slightly due to the replacement of $\mathrm{N}$ by $\mathrm{O}$ in the beginning of oxidation, whereas the $\mathrm{N} /(\mathrm{Ta}+\mathrm{Zr})$ ratio of the annealed $\mathrm{Ta}_{0.84} \mathrm{Zr}_{0.16} \mathrm{~N}_{0.40}$ thin films maintained a level similar to that at the as-deposited state due to the high degree of understoichiometric structure.

The XRD patterns of the 4-h-annealed Ta-Zr-N thin films (data not shown) did not differ from those of the corresponding as-deposited thin films. Figure 5 presents the XRD patterns of the 8-h-annealed Ta-Zr-N thin films, which also exhibited reflections similar to those of the as-deposited thin films except that a wide diffraction reflection appeared at the $2 \theta$ angle of approximately $30^{\circ}$ for the $\mathrm{Ta}_{0.33} \mathrm{Zr}_{0.67} \mathrm{~N}_{0.68}$ thin film, which is attributable to the formation of a surface oxide scale 
comprising $\mathrm{ZrO}_{2}$. The thicknesses of surface oxide scales were 131, 136, 62, and $0 \mathrm{~nm}$ and 221, 195, 151, and $41 \mathrm{~nm}$ (Figure 6) for the 4- and 8-h-annealed $\mathrm{Ta}_{0.84} \mathrm{Zr}_{0.16} \mathrm{~N}_{0.40}, \mathrm{Ta}_{0.81} \mathrm{Zr}_{0.19} \mathrm{~N}_{0.52}, \mathrm{Ta}_{0.58} \mathrm{Zr}_{0.42} \mathrm{~N}_{0.59}$, and $\mathrm{Ta}_{0.33} \mathrm{Zr}_{0.67} \mathrm{~N}_{0.68}$ thin films, respectively. Figure 7a shows the cross-sectional TEM image of the 8-h-annealed $\mathrm{Ta}_{0.58} \mathrm{Zr}_{0.42} \mathrm{~N}_{0.59}$ thin film, whose selected area diffraction pattern exhibits an fcc phase. The high-resolution image (Figure $7 b$ ) of the outermost surface region exhibits an amorphous oxide scale of approximately $13 \mathrm{~nm}$. Lattice fringes with d-spacings of 0.224 and $0.259 \mathrm{~nm}$, which respectively correlate to the stacking of (200) and (111) planes, were identified beneath the outermost surface oxide region. The dark-field image corresponding to the (111) diffraction spot in Figure 7a reveals a fine columnar structure with a width of $30 \mathrm{~nm}$ (Figure 7c). Figure 8a shows the cross-sectional TEM image of the 8-h-annealed $\mathrm{Ta}_{0.33} \mathrm{Zr}_{0.67} \mathrm{~N}_{0.68}$ thin film, whose columnar structure and diffraction pattern are more evident than those of the annealed $\mathrm{Ta}_{0.58} \mathrm{Zr}_{0.42} \mathrm{~N}_{0.59}$ thin film. Figure $8 \mathrm{~b}$ indicates that crystalline $\mathrm{ZrO}_{2}$ domains were observed in the surface oxide scale of the annealed $\mathrm{Ta}_{0.33} \mathrm{Zr}_{0.67} \mathrm{~N}_{0.68}$ thin film. The lattice fringes of (200) and (111) planes in the columnar nitride structure show d-spacings of 0.229 and $0.263 \mathrm{~nm}$, respectively. Figure $8 \mathrm{c}$ exhibits the dark-field image corresponding to the (111) diffraction spot in Figure $8 \mathrm{a}$ and reveals a coarser columnar width of $95 \mathrm{~nm}$. The oxide scales of $\mathrm{Ta}_{0.84} \mathrm{Zr}_{0.16} \mathrm{~N}_{0.40}$ and $\mathrm{Ta}_{0.81} \mathrm{Zr}_{0.19} \mathrm{~N}_{0.52}$ were inferred to be amorphous because no oxide reflections were observed in their XRD patterns.

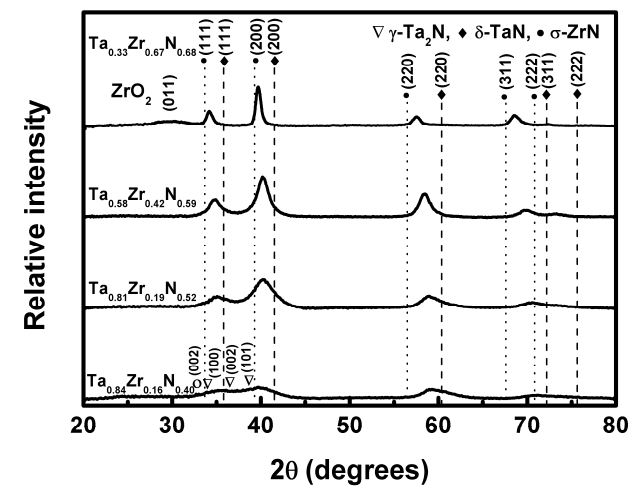

Figure 5. XRD patterns of the Ta- $\mathrm{Zr}-\mathrm{N}$ thin films after annealing at $600{ }^{\circ} \mathrm{C}$ in $15 \mathrm{ppm} \mathrm{O}_{2}-\mathrm{N}_{2}$ for $8 \mathrm{~h}$.
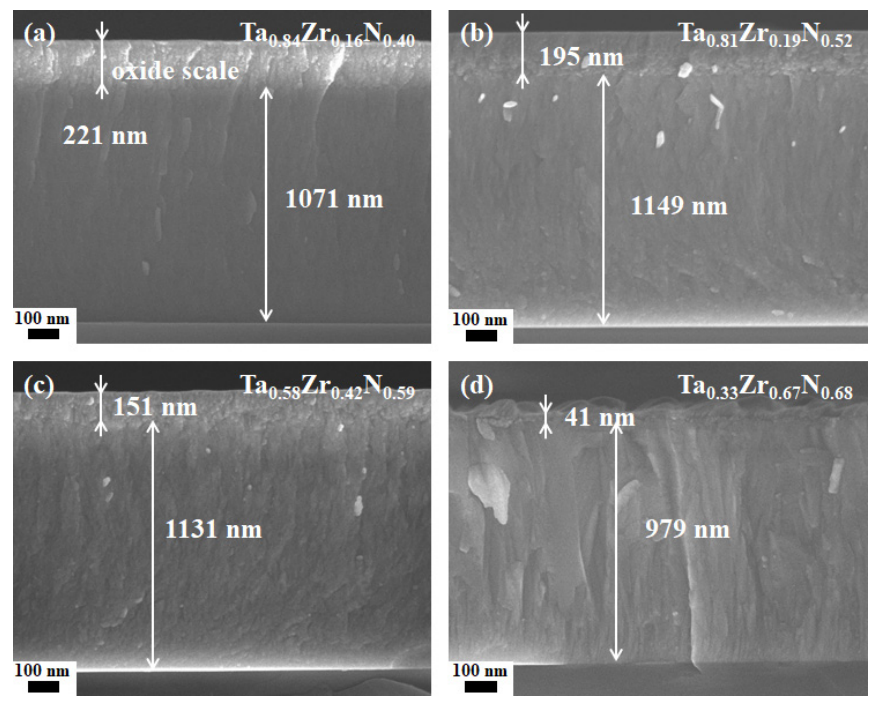

Figure 6. Cross-sectional SEM images of the Ta-Zr-N thin films after annealing at $600{ }^{\circ} \mathrm{C}$ in $15 \mathrm{ppm}$ $\mathrm{O}_{2}-\mathrm{N}_{2}$ for 8 h. (a) $\mathrm{Ta}_{0.84} \mathrm{Zr}_{0.16} \mathrm{~N}_{0.40}$; (b) $\mathrm{Ta}_{0.81} \mathrm{Zr}_{0.19} \mathrm{~N}_{0.52}$; (c) $\mathrm{Ta}_{0.58} \mathrm{Zr}_{0.42} \mathrm{~N}_{0.59}$; (d) $\mathrm{Ta}_{0.33} \mathrm{Zr}_{0.67} \mathrm{~N}_{0.68}$. 

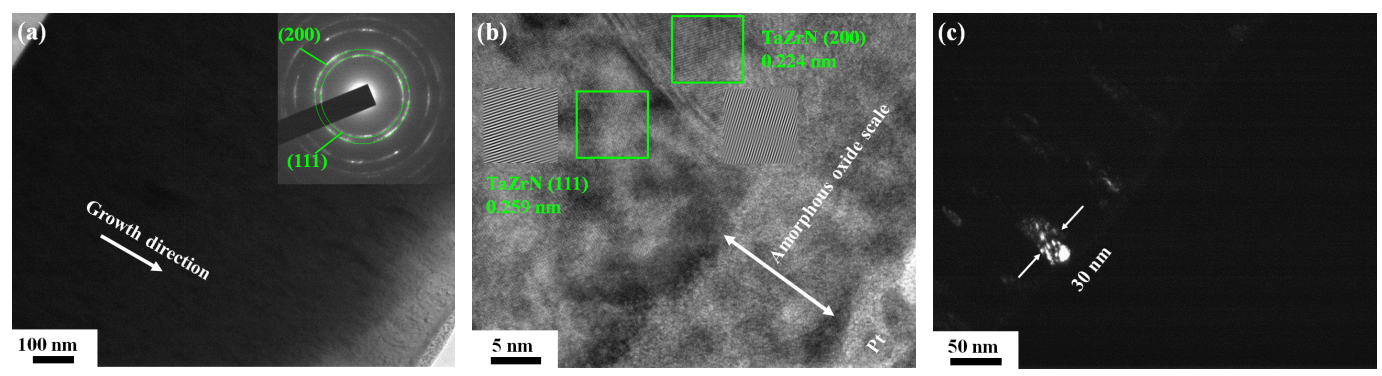

Figure 7. (a) Cross-sectional TEM image of the $\mathrm{Ta}_{0.58} \mathrm{Zr}_{0.42} \mathrm{~N}_{0.59}$ thin film after annealing at $600{ }^{\circ} \mathrm{C}$ in 15 ppm $\mathrm{O}_{2}-\mathrm{N}_{2}$ for $8 \mathrm{~h}$; (b) high-resolution image of the outermost surface region; and (c) dark-field image corresponding to the (111) diffraction spot.
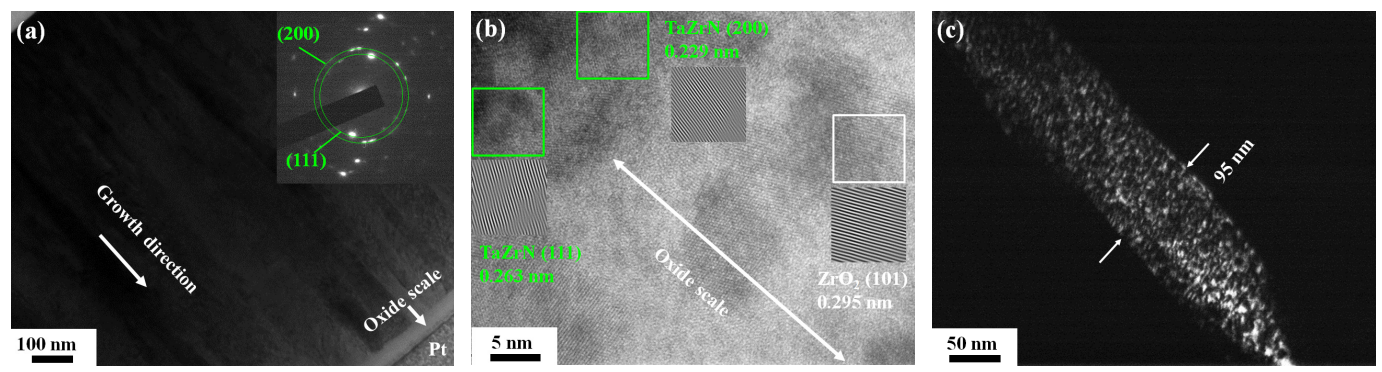

Figure 8. (a) Cross-sectional TEM image of the $\mathrm{Ta}_{0.33} \mathrm{Zr}_{0.67} \mathrm{~N}_{0.68}$ thin film after annealing at $600{ }^{\circ} \mathrm{C}$ in 15 ppm $\mathrm{O}_{2}-\mathrm{N}_{2}$ for $8 \mathrm{~h}$; (b) high-resolution image of the near-surface region; and (c) dark-field image corresponding to the (111) diffraction spot.

The vital characteristics of the protective coatings on glass molding dies were high hardness, low surface roughness, and chemical inertness against moldable optical glasses $[6,8,32,33]$. The formation of amorphous surface oxide scales on high-Ta-content $\mathrm{Ta}-\mathrm{Zr}-\mathrm{N}$ thin films restricted the increase in surface roughness relative to that of crystalline oxide scales formed on high-Zr-content $\mathrm{Ta}_{0.33} \mathrm{Zr}_{0.67} \mathrm{~N}_{0.68}$ thin films (Table 3). Since the hardness values of the moldable optical glasses ranged from 3.2 to $7.0 \mathrm{GPa}$, the protective coatings with a hardness higher than $10 \mathrm{GPa}$ were preferred [8]. Although the hardness measurement of the annealed thin films included the contribution of surface oxide scale, this hardness value implied a realistic strength against the glasses in the molding process. The nanoindentation hardnesses decreased to 20.9, 21.5, 25.7, and $28.3 \mathrm{GPa}$ for the 4-h-annealed $\mathrm{Ta}_{0.84} \mathrm{Zr}_{0.16} \mathrm{~N}_{0.40}, \mathrm{Ta}_{0.81} \mathrm{Zr}_{0.19} \mathrm{~N}_{0.52}, \mathrm{Ta}_{0.58} \mathrm{Zr}_{0.42} \mathrm{~N}_{0.59}$, and $\mathrm{Ta}_{0.33} \mathrm{Zr}_{0.67} \mathrm{~N}_{0.68}$ thin films (Table 3), respectively; furthermore, the nanoindentation hardnesses decreased to 18.0, 19.5, 24.8, and 19.3 GPa after $8 \mathrm{~h}$ of annealing, respectively. Both the $H^{3} / E^{2}$ ratio and elastic recovery $\mathrm{W}_{\mathrm{e}}$ exhibited decreased trends with increasing the annealing time due to the formation of surface oxide. The residual stress of annealed $\mathrm{Ta}_{0.84} \mathrm{Zr}_{0.16} \mathrm{~N}_{0.40}$ and $\mathrm{Ta}_{0.81} \mathrm{Zr}_{0.19} \mathrm{~N}_{0.52}$ thin films decreased to a range of -2.6 to $-3.5 \mathrm{GPa}$ (Table 3). The annealed $\mathrm{Ta}_{0.58} \mathrm{Zr}_{0.42} \mathrm{~N}_{0.59}$ and $\mathrm{Ta}_{0.33} \mathrm{Zr}_{0.67} \mathrm{~N}_{0.68}$ thin films exhibited local detachment after annealing; hence, the residual stress could not be evaluated. In a previous study [30], the nanoindentation hardness values of the HIPIMS-fabricated $\mathrm{ZrN}_{x}$ thin films declined from 26-27 GPa to less than $10 \mathrm{GPa}$ after they were annealed at $600{ }^{\circ} \mathrm{C}$ in $15 \mathrm{ppm} \mathrm{O}_{2}-\mathrm{N}_{2}$ for $2 \mathrm{~h}$ owing to the formation of crystalline $\mathrm{ZrO}_{2}$ scales, which was accompanied by an increase in the surface roughness from 0.5 to $3-6 \mathrm{~nm}$.

\section{Conclusions}

We reported the preparation of understoichiometric Ta-Zr-N thin films with atomic ratios $(\mathrm{N} /(\mathrm{Ta}+\mathrm{Zr}))$ of 0.40-0.68 through HIPIMS/RFMS co-sputtering. The as-deposited high-Ta-content Ta-Zr-N thin films $\mathrm{Ta}_{0.84} \mathrm{Zr}_{0.16} \mathrm{~N}_{0.40}, \mathrm{Ta}_{0.81} \mathrm{Zr}_{0.19} \mathrm{~N}_{0.52}$, and $\mathrm{Ta}_{0.58} \mathrm{Zr}_{0.42} \mathrm{~N}_{0.59}$ exhibited nanoindentation hardnesses of $32-35 \mathrm{GPa}$, Young's moduli of $258-311 \mathrm{GPa}, \mathrm{H}^{3} / E^{2}$ values of $0.44-0.50 \mathrm{GPa}$, 
elastic recovery of $73 \%-76 \%$, and surface roughnesses of $0.4-0.5 \mathrm{~nm}$. The HIPIMS technique helps to fabricate dense and smooth thin films. After annealing at $600{ }^{\circ} \mathrm{C}$ in a $15-\mathrm{ppm} \mathrm{O}_{2}-\mathrm{N}_{2}$ atmosphere for $4 \mathrm{~h}$, the nanoindentation hardnesses decreased to 21-26 GPa and the surface roughnesses increased to $0.5-1.1 \mathrm{~nm}$. The nanoindentation hardnesses further decreased to 18-25 GPa and the surface roughnesses further increased to $1.2-1.6 \mathrm{~nm}$ after $8 \mathrm{~h}$ of annealing. The introduction of Ta into the HIPIMS-fabricated $\mathrm{ZrN}$ thin films evidently raised the hardness values in the as-deposited state and varied the oxide scale to be a $\mathrm{ZrO}_{2}$-dominant amorphous layer after annealing; the amorphous layer decreased the oxidation rate and reduced the declining trend of the hardness during annealing. Amorphous surface oxide scales restricted an increase in surface roughness. The HIPIMS/RFMS-co-sputtered Ta-Zr-N thin films exhibited a nanoindentation hardness of 30-35 GPa with a $\mathrm{Zr} /(\mathrm{Ta}+\mathrm{Zr})$ ratio range of 0.16-0.67; this range was wider than those of the conventional DC-sputtered Ta-Zr-N thin films with a hardness $>30 \mathrm{GPa}$.

Acknowledgments: The financial supports of this work from the Ministry of Science and Technology, Taiwan, under contract nos. 104-2622-E-131-005 and 105-2221-E-131-004 are appreciated.

Author Contributions: Li-Chun Chang designed the experiments and wrote the paper; Ching-Yen Chang performed the experiments; and Ya-Wen You analyzed the TEM data.

Conflicts of Interest: The authors declare no conflict of interest. The founding sponsors had no role in the design of the study; in the collection, analyses, or interpretation of data; in the writing of the manuscript; or in the decision to publish the results.

\section{References}

1. Aouadi, S.M.; Filip, P.; Debessai, M. Characterization of tantalum zirconium nitride sputter-deposited nanocrystalline coatings. Surf. Coat. Technol. 2004, 187, 177-184. [CrossRef]

2. Aouadi, S.M. Structural and mechanical properties of TaZrN films: Experimental and ab initio studies. J. Appl. Phys. 2006, 99, 053507. [CrossRef]

3. Ruan, J.L.; Huang, J.L.; Lu, H.H.; Chen, J.S.; Lii, D.F. Effects of the Ta content on the microstructure and electrical property of reactively sputtered $\mathrm{Ta}_{x} \mathrm{Zr}_{1-x} \mathrm{~N}$ thin films. Thin Solid Films 2011, 519, 4987-4991. [CrossRef]

4. Abadias, G.; Kanoun, M.B.; Goumri-Said, S.; Koutsokeras, L.; Dub, S.N.; Djemia, P. Electronic structure and mechanical properties of ternary $\mathrm{ZrTaN}$ alloys studied by ab initio calculations and thin-film growth experiments. Phys. Rev. B 2014, 90, 114107. [CrossRef]

5. Abadias, G.; Djemia, P.; Belliard, L. Alloying effects on the structure and elastic properties of hard coatings based on ternary transition metal $(M=\mathrm{Ti}$, Zr or Ta) nitrides. Surf. Coat. Technol. 2014, 257, 129-137. [CrossRef]

6. Chang, L.C.; Chang, C.Y.; Chen, Y.I. Mechanical properties and oxidation resistance of reactively sputtered $\mathrm{Ta}_{1-x} \mathrm{Zr}_{x} \mathrm{~N}_{y}$ thin films. Surf. Coat. Technol. 2015, 280, 27-36. [CrossRef]

7. Liu, S.C.; Chen, Y.I.; Tsai, H.Y.; Lin, K.C.; Chen, Y.H. Thermal stability of Ir-Re coatings annealed in oxygen-containing atmospheres. Surf. Coat. Technol. 2013, 237, 105-111. [CrossRef]

8. Liu, S.C.; Chen, Y.I.; Shyu, J.J.; Tsai, H.Y.; Lin, K.Y.; Chen, Y.H.; Lin, K.C. The chemical inertness of Ir-Re and Ta-Ru coatings in molding $\mathrm{B}_{2} \mathrm{O}_{3}-\mathrm{ZnO}-\mathrm{La}_{2} \mathrm{O}_{3}$-based glass. Surf. Coat. Technol. 2014, 259, 352-357. [CrossRef]

9. Kouznetsov, V.; Macák, K.; Schneider, J.M.; Helmersson, U.; Petrov, I. Functional differences between the external and protoplasmic surfaces of plasma membranes in activating vaccinia virus infectivity. Surf. Coat. Technol. 1990, 122, 290-293. [CrossRef]

10. Helmersson, U.; Lattemann, M.; Bohlmark, J.; Ehiasarian, A.P.; Gudmundsson, J.T. Ionized physical vapor deposition (IPVD): A review of technology and applications. Thin Solid Films 2006, 513, 1-24. [CrossRef]

11. Purandare, Y.P.; Ehiasarian, A.P.; Hovsepian, P.E. Structure and properties of $\mathrm{ZrN}$ coatings deposited by high power impulse magnetron sputtering technology. J. Vac. Sci. Technol. A 2011, 29, 011004. [CrossRef]

12. Schmidt, S.; Czigány, Z.; Greczynski, G.; Jensen, J.; Hultman, L. Influence of inert gases on the reactive high power pulsed magnetron sputtering process of carbon-nitride thin films. J. Vac. Sci. Technol. A 2013, 31, 011503. [CrossRef] 
13. Magnus, F.; Ingason, A.S.; Olafsson, S.; Gudmundsson, J.T. Nucleation and resistivity of ultrathin TiN films grown by high-power impulse magnetron sputtering. IEEE Electron. Dev. Lett. 2012, 33, 1045-1047. [CrossRef]

14. Alami, J.; Sarakinos, K.; Mark, G.; Wuttig, M. On the deposition rate in a high power pulsed magnetron sputtering discharge. Appl. Phys. Lett. 2006, 89, 154104. [CrossRef]

15. Greczynski, G.; Lu, J.; Jensen, J.; Bolz, S.; Kölker, W.; Schiffers, C.; Lemmer, O.; Greene, J.E.; Hultman, L. A review of metal-ion-flux-controlled growth of metastable TiAlN by HIPIMS/DCMS Co-sputtering. Surf. Coat. Technol. 2014, 257, 15-25. [CrossRef]

16. Ding, J.; Zhang, T.; Yun, J.M.; Kang, M.C.; Wang, Q.; Kim, K.H. Microstructure, mechanical, oxidation and corrosion properties of the Cr-Al-Si-N coatings deposited by a hybrid sputtering system. Coatings 2017, 7, 119. [CrossRef]

17. Oliver, W.C.; Pharr, G.M. An improved technique for determining hardness and elastic modulus using load and displacement sensing indentation experiments. J. Mater. Res. 1992, 7, 1564-1583. [CrossRef]

18. Simmons, G.; Wang, H. Single Crystal Young's Constants and Calculated Aggregate Properties: A Handbook; MIT Press: Cambridge, MA, USA, 1971.

19. Janssen, G.C.A.M.; Abdalla, M.M.; van Keulen, F.; Pujada, B.R.; van Venrooy, B. Celebrating the 100th anniversary of the Stoney equation for film stress: Developments from polycrystalline steel strips to single crystal silicon wafers. Thin Solid Films 2009, 517, 1858-1867. [CrossRef]

20. Thod, L.E. Transition Metal Carbides and Nitrides; Academic Press: New York, NY, USA, 1971.

21. Matenoglou, G.M.; Koutsokeras, L.E.; Lekka, C.E.; Abadias, G.; Kosmidis, C.; Evangelakis, G.A.; Patsalas, P. Structure, stability and bonding of ternary transition metal nitrides. Surf. Coat. Technol. 2009, 204, 911-914. [CrossRef]

22. Barin, I. Thermochemical Data of Pure Substances, 3rd ed.; VCH: New York, NY, USA, 1995.

23. Hurkmans, T.; Lewis, D.B.; Paritong, H.; Brooks, J.S.; Münz, W.D. Influence of ion bombardment on structure and properties of unbalanced magnetron grown $\mathrm{CrN}_{x}$ coatings. Surf. Coat. Technol. 1999, 114, 52-59. [CrossRef]

24. Musil, J.; Šícha, J.; Heřman, D.; Čerstvý, R. Role of energy in low-temperature high-rate formation of hydrophilic $\mathrm{TiO}_{2}$ thin films using pulsed magnetron sputtering. J. Vac. Sci. Technol. A 2007, 25, 666-674. [CrossRef]

25. Musil, J. Hard nanocomposite coatings: Thermal stability, oxidation resistance and toughness. Surf. Coat. Technol. 2012, 207, 50-65. [CrossRef]

26. Musil, J.; Jaroš, M.; Čerstvý, R.; Haviar, S. Evolution of microstructure and macrostress in sputtered hard $\mathrm{Ti}(\mathrm{Al}, \mathrm{V}) \mathrm{N}$ films with increasing energy delivered during their growth by bombarding ions. J. Vac. Sci. Technol. A 2017, 35, 020601. [CrossRef]

27. Zhou, Y.L.; Niinomi, M.; Akahori, T. Changes in mechanical properties of Ti alloys in relation to alloying additions of Ta and Hf. Mater. Sci. Eng. A 2008, 483-484, 153-156. [CrossRef]

28. Tsui, T.Y.; Pharr, G.M.; Oliver, W.C.; Bhatia, C.S.; White, R.L.; Anders, S.; Anders, A.; Brown, I.G. Nanoindentation and nanoscratching of hard carbon coatings for magnetic disks. Mater. Res. Soc. Symp. Proc. 1995, 383, 447-452. [CrossRef]

29. Musil, J.; Kunc, F.; Zeman, H.; Poláková, H. Relationships between hardness, Young's modulus and elastic recovery in hard nanocomposite coatings. Surf. Coat. Technol. 2002, 154, 304-313. [CrossRef]

30. Chang, L.C.; Chang, C.Y.; Chen, Y.I.; Kao, H.L. Mechanical properties and oxidation behavior of $\mathrm{ZrN}_{x}$ thin films fabricated through high-power impulse magnetron sputtering deposition. J. Vac. Sci. Technol. A 2016, 34, 02D107. [CrossRef]

31. Bielawski, M. Residual stress control in TiN/Si coatings deposited by unbalanced magnetron sputtering. Surf. Coat. Technol. 2006, 200, 3987-3995. [CrossRef]

32. Chen, Y.I.; Wang, H.H. Oxidation resistance and mechanical properties of $\mathrm{Cr}-\mathrm{Ta}-\mathrm{Si}-\mathrm{N}$ coatings in glass molding processes. Surf. Coat. Technol. 2014, 260, 118-125. [CrossRef]

33. Chen, Y.I.; Cheng, Y.R.; Chang, L.C.; Lu, T.S. Chemical inertness of Ta-Si-N coatings in glass molding. Thin Solid Films 2015, 584, 66-71. [CrossRef]

(C) 2017 by the authors. Licensee MDPI, Basel, Switzerland. This article is an open access article distributed under the terms and conditions of the Creative Commons Attribution (CC BY) license (http://creativecommons.org/licenses/by/4.0/). 